\title{
Retraction Note: Esoteric Connective Tissue Therapy for chronic low back pain to reduce pain, and improve functionality and general well-being compared with physiotherapy: study protocol for a randomised controlled trial
}

Christoph Schnelle ${ }^{1 *}$, Steffen Messerschmidt ${ }^{6}$, Eunice J. Minford ${ }^{2,3}$, Kate Greenaway-Twist ${ }^{7}$, Maxine Szramka ${ }^{4}$, Marianna Masiorski ${ }^{8}$, Michelle Sheldrake ${ }^{5}$ and Mark Jones ${ }^{1}$

Retraction Note: Trials (2017) 18:328

https://doi.org/10.1186/s13063-017-2055-8

The authors are retracting this article as ethical approval has been withdrawn. The corresponding author, Christopher Schnelle, stated on behalf of all coauthors that they agree to this retraction.

\section{Author details}

${ }^{1}$ School of Public Health, University of Queensland, Herston Road, Herston,

QLD, Australia. ${ }^{2}$ Department of Surgery, Antrim Area Hospital, 45 Bush Rd, Antrim BT41 2RL, UK. ${ }^{3}$ Queen's University Belfast, University Rd, Belfast BT7

1NN, UK. ${ }^{4}$ The Rheumatology Centre, Sydney and Nowra, Australia.

${ }^{5}$ University of New South Wales, High Street, Kensington, NSW, Australia.

${ }^{6}$ Total Health From Inside Out Pty Ltd, Brisbane and Gold Coast, Australia. ${ }^{7}$ Independent physiotherapist, practising in Goonellabah, Australia.

${ }^{8}$ Independent psychologist, practising in Sunshine Coast, Australia.

Published online: 04 March 2021

\section{Reference}

1. Schnelle C, et al. Esoteric Connective Tissue Therapy for chronic low back pain to reduce pain, and improve functionality and general well-being compared with physiotherapy: study protocol for a randomised controlled trial. Trials. 2017;18:328. https://doi.org/10.1186/s13063-017-2055-8.

The original article can be found online at https://doi.org/10.1186/s13063017-2055-8.

* Correspondence: christoph.schnelle@uq.net.au

'School of Public Health, University of Queensland, Herston Road, Herston, QLD, Australia

Full list of author information is available at the end of the article

(c) The Author(s). 2021 Open Access This article is licensed under a Creative Commons Attribution 4.0 International License, which permits use, sharing, adaptation, distribution and reproduction in any medium or format, as long as you give appropriate credit to the original author(s) and the source, provide a link to the Creative Commons licence, and indicate if changes were made. The images or other third party material in this article are included in the article's Creative Commons licence, unless indicated otherwise in a credit line to the material. If material is not included in the article's Creative Commons licence and your intended use is not permitted by statutory regulation or exceeds the permitted use, you will need to obtain permission directly from the copyright holder. To view a copy of this licence, visit http://creativecommons.org/licenses/by/4.0/ The Creative Commons Public Domain Dedication waiver (http://creativecommons.org/publicdomain/zero/1.0/) applies to the data made available in this article, unless otherwise stated in a credit line to the data. 